\title{
On the Early History of Museum Environment Control NATIONALMUSEUM AND GRIPSHOLM CASTLE IN SWEDEN, C.1866-1932
}

\author{
Mattias Legnér
}

\begin{abstract}
Despite the fact that there have been investigations into the historical development of indoor climate recommendations, to date very little research has been carried out on how climate control in museums was actually implemented in the past. This article examines the development of climate control in two Swedish museum buildings up until the 1930s: Nationalmuseum and Gripsholm Castle. Nationalmuseum was erected to make the state collections more accessible to the public and to provide monitoring and central heating. At that time knowledge of climatic conditions in museums was tacit and based on personal experience rather than on scientific studies. However, in the early twentieth century the problem of managing museum climate increased as curators became more aware of the dehydrating effects of central heating on panels and polychrome wood. The first successful attempts to automatically control indoor climate were carried out at Gripsholm in the 1920s. The focus was then on monitoring and controlling temperature rather than relative humidity, but these early attempts also showed that extreme levels of humidity could be avoided in an environment that had never been designed for permanent heating. This article examines attempts at managing indoor climate between the 1860 s and the 1930s.
\end{abstract}

\section{INTRODUCTION}

As indoor environmental control gradually improved in the late nineteenth century, museums began to develop an interest in observing and influencing the indoor climate of their buildings. The notion of indoor comfort in the US and Western Europe was shaped in the early decades of the twentieth century, and this affected to a great extent the environment in which museum collections were to be kept for the rest of the century. The first evaporative air cooling system was developed in the US in the early 1900s [1]. It is known that the climatic conditions in museums, as well as the homes of collectors, were in general lower in temperature and more humid before the introduction of central heating, when buildings began to be heated both day and night [2]. In order to reflect more accurately upon the suitability of museum environments, we should scrutinize what historical sources reveal about the development of museum climate and the management of collections in the past.

Received July 2010
The history of museum climate is one topic where there is much research left to be done. Except for investigations of scientific aspects of the development of indoor climate recommendations, very little has been written on how indoor climate control has been achieved in the past. In England, research on the effects of pollution, light and heat on paintings commenced in the mid-nineteenth century, prompted by problems at the National Gallery [3]. However, the 1920s seem to have been a turning point in the approach to museum climate in both Western Europe and North America, coinciding with the advent of the systematic application of science within conservation. In both Germany and Great Britain, antiquities had been stored in presumed safe places during World War I, but which often had unsuitable climatic conditions for the objects [4]. In Britain, part of the British Museum collection was evacuated to the damp Holborn Post Office tunnel in 1918 [5]. Soon after the war the British Museum opened a laboratory for examining and repairing damage caused by fluctuating humidity and temperature [6]. Similarly, in Germany the Staatsmuseum in Berlin began to apply natural sciences in conservation in the 1920s [7]. 
Sweden, however, was not engaged in the war and thus did not develop the same need for post-war treatment of its cultural heritage. Nonetheless, an increasing interest in the museum environment began to emerge at about the same time as in Great Britain and Germany. Why this happened cannot be explained by referring just to one or two factors, but is rather complicated and relates to social and economic changes in Swedish society at the time. Heating, either central or electrical, was becoming common in both public buildings and private dwellings, and the attendant effects on works of art, although observable, were not very clearly understood. There was an emphasis on keeping the temperature to a minimum, which is understandable as temperature was much easier to record than humidity, but the relationship between temperature and relative humidity (RH) was not known among Swedish curators and conservators.

Central heating meant that homes could be heated both day and night, making the indoor climate very dry in winter. Collectors of art in North America discovered that the increased heat in wintertime caused more swings in humidity levels, making their panel paintings crack, blister and flake [8]. At Yale University Art Gallery, for instance, a steam heating system was installed in 1874 with the intention of reducing the deterioration rate of the panel paintings [9]. An increased concern for the effects of heat and humidity on collections caused some museums in Europe and North America to install climate control systems in the 1910s and 1920s [10]. In the US, the Museum of Fine Arts in Boston had installed humidity controlling and air filtering systems as early as 1908. It was found that RH was best kept within the range of $55-60 \%$ regardless of the season or temperature, but the reasons for this conclusion are not clear since there is no documentation left on what kind of experiments were carried out. Water sprays were not yet being used to cool the air, but rather to clean it of pollution. The Cleveland Museum of Art followed suit in 1915 with a so-called 'plenum air system' which cleaned air going into the galleries with a water spray. In 1931 it was stated that on the basis of 15 years of RH and temperature measurements, the ideal $\mathrm{RH}$ for the Cleveland collection was between 50 and 55 per cent, although (as in the case of Boston), the precise reasons by which this conclusion was reached were not given [11].

At the National Gallery in London the possibilities for an air conditioning system were investigated in 1930. In the winter of 1929 blistering and flaking on the museum's panel paintings had increased [12]. The problem was thought to be due to reduced humidity which caused the wooden panels to warp. Tests were run on original panel paintings in the 1930s, and while the conclusions were not very clear, nevertheless these showed that paint flaking was related to long-term humidity changes. In 1934, a system for partial air conditioning was installed and tested at Hampton Court Palace, which houses canvas paintings from the late fifteenth century, with the goal of keeping $\mathrm{RH}$ within the range of $55-75 \%$ and the temperature between 12 and $18^{\circ} \mathrm{C}$ [13]. At Harvard's Fogg Museum, attempts to monitor the relationships between humidity and changes in panel paintings commenced in the mid1930s, but due to the costs involved no significant changes in climate control were made at the time [10].

Why was there a perceived need for greater control of indoor climate? How did museums balance the needs of their collections against the needs of their staff and visitors? What considerations were made when choosing heating and ventilation for a museum at this time? In order to illuminate these questions, archival sources from Nationalmuseum and Riksarkivet (National State Archives) have been examined. Överintendentsämbetet (the Board of Public Works and Buildings) was the keeper of Swedish government buildings until 1918, when the authority was reorganized into Kungl. Byggnadsstyrelsen (the National Board of Public Building and Planning). These authorities were in charge of managing the indoor climate of Nationalmuseum. If the museum had a complaint regarding the climate and desired some modification to the building or its heating system, it had to notify the Board of Public Works and Buildings. The Superintendent would then decide how to act.

In Sweden during the 1920s, Nationalmuseum enjoyed the highest level of conservation practice for its time, owing to the highly significant and prestigious nature of the national treasures held within its collection. The collections were also highly varied in nature, including a wide range of materials: unpainted and polychrome wood, metals, glass, textiles, paper, gypsum, porcelain, bone, marble and other stone types. Demands for a more appropriate climate finally resulted in the installation of a new central heating system in 1930. By examining the case of Nationalmuseum, it is possible to build up a picture of how museum environment and collections care were discussed and handled at the leading arts institution in Sweden. 


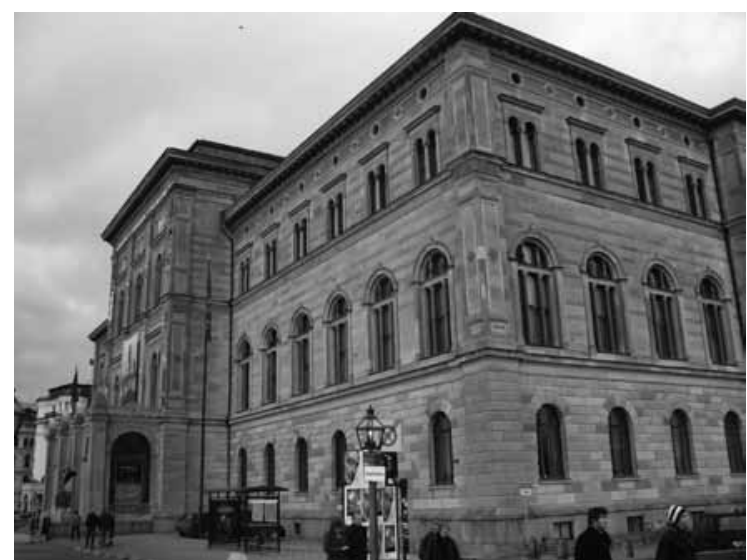

Figure 1 Nationalmuseum in Stockholm, opened in 1866. The façade is covered with limestone, with some ornamentation in Carrara marble. Photo: M. Legnér.

\section{NATIONALMUSEUM AND THE INDOOR CLIMATE, 1860-1920}

The new Nationalmuseum building (Figure 1) was erected in central Stockholm in the early 1860s, opposite the Royal Palace in the Old Town. Several architects were involved in designing the building, of which August Stüler (architect of the Neues Museum in Berlin) was the most predominant. The intention at the time was that all of the royal collections would be kept and displayed in the building. The plan was to bring a total of five collections together under one roof: the Royal Museum; the Royal Swedish Academy of Letters, History and Antiquities; the Royal Coin Cabinet; the Royal Clothing Chamber; and the Royal Armory [14]. In the end, the Royal Library did not become integrated into Nationalmuseum, but was installed in a new building of its own in 1874. Instead, Nationalmuseum came to house the royal art collections.

In 1865 it was decided to move 888 paintings from the Royal Palace, 67 from Drottningholm Palace and 22 from Gripsholm Castle to the new Nationalmuseum building [15]. The overarching purpose of this move was to give the collections a building that could represent the royal power of Sweden, designed as a work of art itself, and to make them available to the public for the first time. The move also had a symbolic significance with the public government taking over the stewardship of these treasures from the monarch. Only a small fraction of the collections that were moved to Nationalmuseum comprised paintings: rune stones, sarcophagi, liturgical

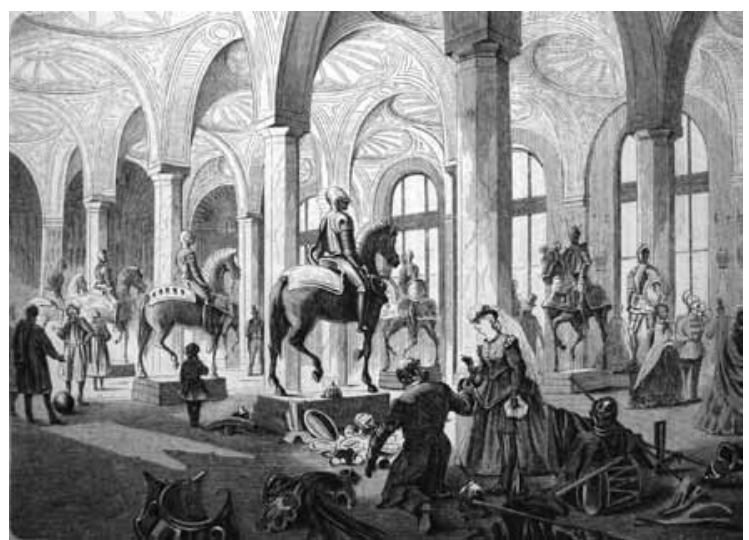

Figure 2 View of the Pillar Hall where the royal armory was kept until 1884, when it was moved to the Royal Place and decorative arts took over the hall. Sveriges familje-journal, 1867.

objects, archaeological findings of gold and silver, royal dresses, about 100 sculptures, arms and armor, porcelain, sketches and models, war trophies, 12,885 drawings and 60,000 engravings were also to be housed in the new premises [14]. In 1884 trophies, arms and armors (Figure 2) were moved to the Royal Palace in order to make room in Nationalmuseum for the decorative arts.

In the same building as Nationalmuseum, which managed the national art collections, was also housed the Royal Swedish Academy of Letters, History and Antiquities (subsequently called the Historical Museum), the historical and archaeological collections of which were located in the ground story and basement of the building. The art collections were kept on the upper two stories where natural light levels were better, since before 1930 the exhibition spaces had no electrical illumination (Figure 3). The collection was arranged according to the concept that the visitor would first encounter objects from the prehistoric and medieval periods, and thereafter strive upwards in order to reach the works of Italian, Dutch, French and Swedish masters. The building, designed as a Venetian Renaissance palace (the only one of its kind in Sweden), was seen by Stüler as a monumental gallery meant to inspire the spectator. It was also to incorporate the latest technology of the time, namely central heating $[16,17]$.

Concerns had been raised in the early 1860 s about the unsuitable environments of the Royal Palace and the church of Riddarholmskyrkan, which housed many significant war trophies from the seventeenth century [14]. In the Royal Palace, paintings had been subjected to 


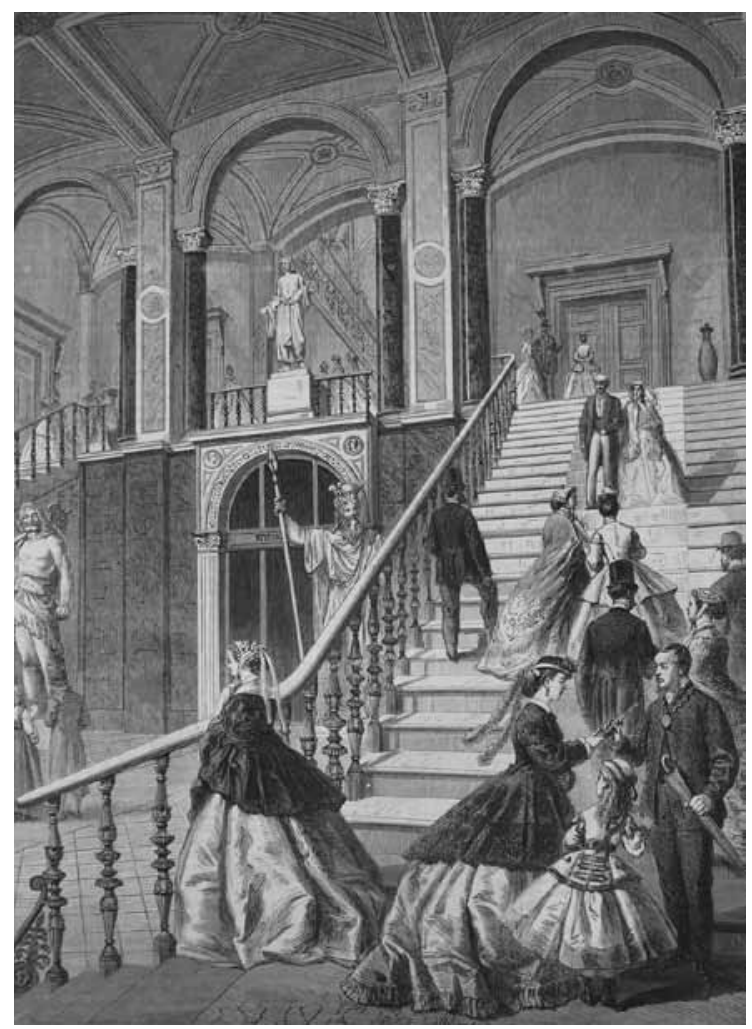

Figure 3 The lounge of Nationalmuseum. Note that visitors entered the galleries fully dressed, leaving only umbrellas or canes with the guard. Children were allowed to enter regardless of age. Ny illustrerad tidning, 1866.

dust as well as soot deposition from candles and torches, while Riddarholmskyrkan church, traditionally the burial place of royalty and gentry, was damp and cold. In 1866 the paintings were in need of conservation.

The precise reasons for installing central heating in the Nationalmuseum building are not known, but it seems clear that it was at least in part intended for the protection of the national treasures. In the budget for the building of 1849 no costs were included for a heating system, but ten years later funding for a central heating system was finally approved by the Swedish parliament following a debate on what sort of system - hot air or hot water - should be selected. In August 1859 the sum of 50,000 Riksdaler Riksmynt had been earmarked for the purchase of heating devices [14]. It is not entirely clear why Perkins ovens were selected in the end; however, what is clear is that the heating system was not viewed as part of the building construction, but as part of the interior. Funding for the interiors such as windows, floors, doors and piping was not released before the beginning of the 1860s. In 1862 the heating system was installed by the German firm of Johannes Haag of Augsburg at the cost of 61,000 Riksdaler Riksmynt.

In 1835 the British Museum in London had installed two such heating systems, one for the reading room and another for the bird and print rooms [18]. The Perkins ovens used hot water circulating through a system of one-inch-thick pipes. The pipes passed through a brick oven located in the basement. The pressurized circuit of pipes was fitted with an expansion loop. When the water expanded through heating it filled the loop, making it possible to heat the water beyond its boiling point. Water reached temperatures of $150-200^{\circ} \mathrm{C}$. The advantage of this system was that the pipework was much thinner than that of a low-pressure hot water heating system, and could more easily be concealed. Moreover, the Perkins oven could achieve the same heating capacity as the larger pipes of earlier hot water systems [19]. A considerable drawback, however, was that to heat the water beyond its boiling point necessitated a significant increase in pressure, and hence risk of explosion. In the first years of use, several accidents occurred which required pipes to be replaced.

In order to heat all the galleries in Nationalmuseum, a total of six ovens were required, fed during the daytime by two firemen. In addition, a supervisor was contracted to live in the building, to operate the systems and ensure that they were not overheated. The first supervisor was a mason who had been involved in the installation of the Perkins ovens and related pipework [20]. Most of the basement was occupied with functions relating to the heating system: the ovens, fuel storage and living quarters for the supervisor.

The museum was heated during the daytime from September until well into May (Figure 4). There were repeated accidents with the ovens: if the water was overheated, pipes would blow and need to be replaced, and until the necessary spare parts had been obtained from Germany and installed the oven would not work. In the first years a supply of spare parts was kept at the museum. However, this supply was not replenished and owing to the many repairs it eventually became exhausted.

The heating system included no radiators. Instead, hot water was fed through $7 \mathrm{~km}$ of pipes embedded in the wooden floors. Heat from these pipes rose through gratings in the floor. As a result of the damage caused by the hot water pipes to the parquet, the inside of the ducts had to be covered with zinc plates to protect the floor 


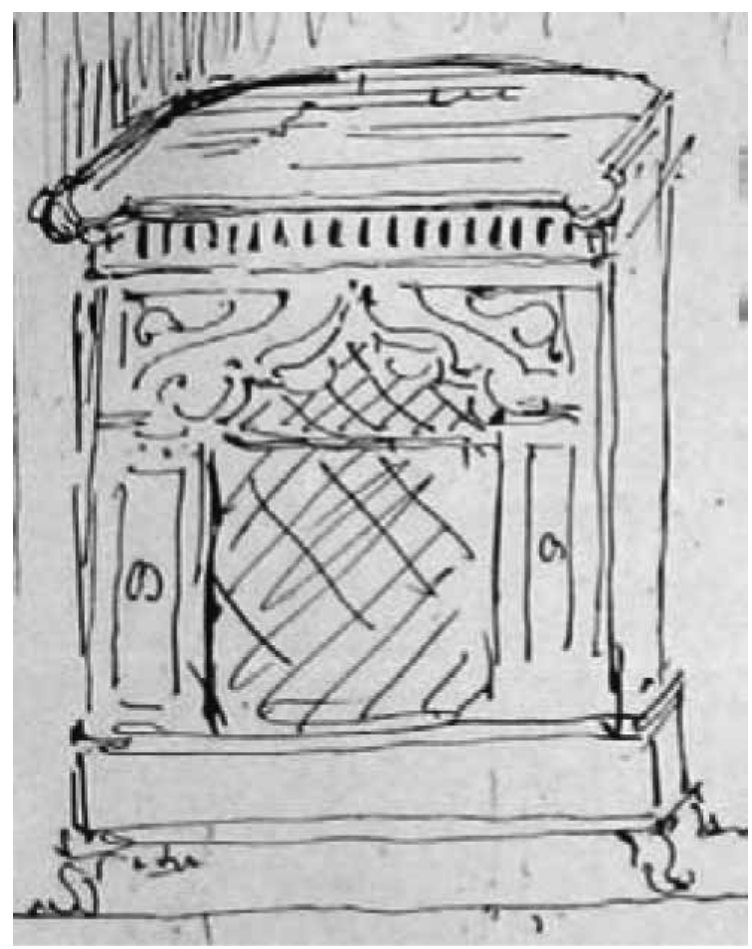

Figure 4 Sketch by manufacturer Carl Bolinder for one of two enclosure casings for Perkins oven piping on the first story of Nationalmuseum [21].

[22]. Even at the time of its introduction this system was not perceived as optimal. The fuel consumption was about 25\% higher than predicted by the manufacturer (3.2 barrels of coal per day instead of the specified 2.6), supposedly due to the large single-pane windows which were far from airtight [23]. The installation of doubleglazed windows was planned but this improvement was later canceled because of financial cutbacks. In the first year of service the annual budget for fuel roughly equaled the combined salary of the three staff members maintaining the heating system and the costs for its repairs [14]. About 60 years later, in 1923-1924, the annual expenses for heating the building were 17009 Kronor, which was roughly the annual wages of a male worker in 1925. At that time a combination of predominantly coke together with birchwood, softwood and coal was used for fuel [24].

A temperature of about $14^{\circ} \mathrm{C}$ seems to have been the norm for the galleries in wintertime, but it was probably lower during the coldest part of the year. According to the trials in 1864 , the system was capable of raising the temperature $16^{\circ} \mathrm{C}$ above outdoor temperature. The top floor with its skylights and insufficient heating sources was most probably considerably colder, while in the attic conditions were similar to those of the exterior climate. Early testing of the Perkins oven also showed that temperature levels varied between different parts of the building, depending on the wind speed and direction [25]. Keeping a steady temperature was not possible in any part of the building, neither in the 1860 s, nor 50 years later. In 1916, for instance, the Director of Antiquities Bernhard Sahlin complained to the Superintendent about the chill in the offices that were only heated with tiled ovens. Around this time the heating system was supplemented with a few electric radiators, and a steam boiler was installed in the basement [26]. Steam heat was used mainly to keep ice and snow off the skylights and not for thermal comfort. However, this circuit did not emit enough heat to entirely keep the snow from building up. Skylights had to be shoveled clean continuously in winter.

The Perkins system heated the galleries but did not serve the office spaces. In fact, the only reason why we know anything at all about temperatures in the building is that the staff complained about the level of thermal comfort. Tiled stoves and also gas stoves were installed in the rooms of the curators and their staff, but in wintertime it could still get uncomfortably cold. In 1902, the Director of Antiquities Hans Hildebrand complained about the cold in his office on the ground floor, which had a temperature of 10 to $12^{\circ} \mathrm{C}$ in wintertime [27]. In 1905 there were three studios on the ground floor, but because of the chilly conditions the antiquarians could not work in them [28].

By far the worst working conditions to be found in the building were in the restorer's workshop (furnished in 1873) in the attic, where the temperature reportedly was between 0 and $6^{\circ} \mathrm{C}$ in winter close to the stove. Already at this time it was seen as a fire hazard to have a stove burning continuously in winter in the attic where a fire could spread rapidly, and where few staff members moved about, but nonetheless the attic continued to be used as a restorer's workshop, and had the same climate as the exterior. In the 1890 s the floor was laid with brick to make the attic more fireproof, a measure which would have made the attic even chillier.

A complaint from the fire department in 1915 about the fire hazard in the attic indicates that it was still used for storing paintings and materials for restoration work. Storage spaces were not part of the building plan, but since the collections were too large for the building, the attic and parts of the basements - premises where you would find the coolest and the dampest climates - 
were taken into use for these purposes. In 1863 it had become apparent that dedicated storage space would be necessary in the near future, and for that reason a floor was fitted in the attic [29]. Objects were moved into the basement, which was very damp (the floors had rotted away) due to the close proximity of the building to Lake Strömmen [30]. Following the complaint in 1915, the attic continued to be used for storage purposes.

In short, Nationalmuseum before the 1920 s was a rather chilly place compared to later comfort standards. It was heated only during working hours, allowing the building to cool off during the night. As a consequence, large amounts of water would condense on the inside of skylights and windows overnight. This water had to be channeled into large collecting tanks to avoid it infiltrating and flooding the galleries on the third floor. In one single winter night as much as 1000 liters of condensed water could be collected inside the building [31].

The central heating system was primarily intended for the galleries, and so additional heat sources such as tile, gas and later also electric stoves had to be used in other spaces. There was little possibility of controlling the indoor climate in the building. Furthermore, the heating system carried significant risks from pipe bursts and fire [32]. In 1919 Otto Janse on behalf of the Director of Antiquities complained to the Superintendent about excessive heating on the first floor, where the collection of medieval polychrome wood was kept. He demanded that the pipes be insulated as attempts to lower the water temperature in the pipes had not worked. Accordingly, the pipes in the floor of the gallery were insulated with asbestos paper, but apparently this did not decrease air temperature [33]. To combat the effects of this, the Historical Museum attempted to add moisture to the air by placing open water containers in the exhibition spaces. However, the problem of dry air was to become more serious when the temperature was raised throughout the building after 1930 .

\section{FIRST ATTEMPTS AT CLIMATE CONTROL, GRIPSHOLM CASTLE 1922-1931}

Among Nationalmuseum's collections is the national portrait gallery. The collection has been kept at the royal Renaissance castle of Gripsholm for a long time. Before the 1920s Gripsholm (Figure 5) was an unheated environment. Tiled ovens had been employed since the sixteenth century, but by the early twentieth century they were no longer in use. At this time the castle was no longer occupied. In 1880, the portrait

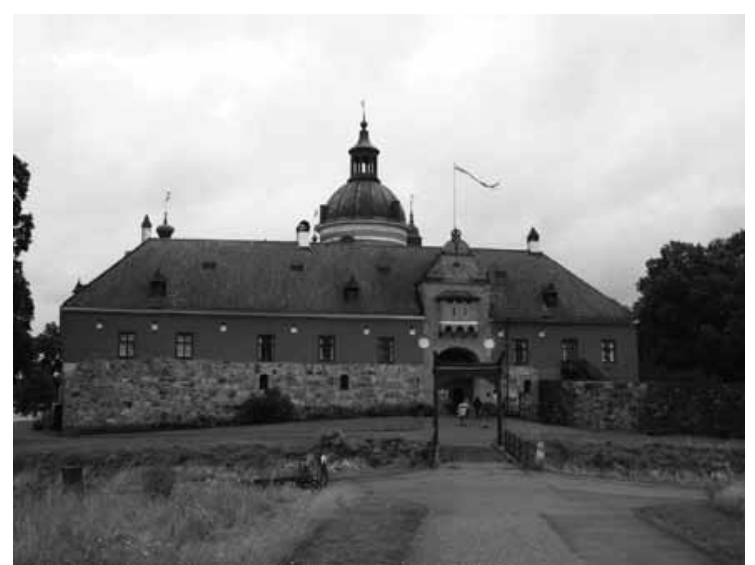

Figure 5 Gripsholm Castle in Mariefred. Photo: M. Legnér.

collection at Gripsholm consisted of 1704 items [34]. In wintertime the thick outer walls experienced significant condensation, causing damage to both the building itself and its valuable collections. In winter the temperature would drop to -7 or $-8^{\circ} \mathrm{C}$, with a RH level of $90-100 \%$ according to statistics collected by the curator in the early 1920s. Especially during the spring and autumn, when the walls were either warming up or cooling down and causing significant risk of condensation, it was feared that 'the relatively delicate works of art would eventually be destroyed' [35]. Part of the problem was the habit of airing in early Spring. When warm air from the outside was being let into the cool building, the humidity of this warmer air would condense on the walls and the paintings. The reason for airing churches was to let heat into the church to increase comfort.

During the cooler months, the thick brick walls of Gripsholm could buffer much moisture that would be slowly released in the springtime. Consequently the environmental problems at Gripsholm were the opposite of those experienced at Nationalmuseum, as the climate in the castle was too humid for paintings rather than too dry. The reason for this difference was that Nationalmuseum was heated for eight months in the year while Gripsholm was unheated.

In the early twentieth century the portrait collection was undergoing extensive restoration. For financial reasons it was in the interest of Nationalmuseum to minimize the need for future interventions to the collection. The curator of Nationalmuseum, Axel Gauffin, expressed concern regarding the state of the art collections kept at the royal palaces of Gripsholm and Drottningholm Palace when in 1924 he said that: 
[the] historically as well as artistically highly interesting portrait gallery at Gripsholm, which has suffered precariously during the long winters in the unheated Vasa castle, is beginning to face a brighter future thanks to the recent generosity of the parliament. The turn has come to the collection at Drottningholm, in many ways comparable to the one of Gripsholm. There is no grant for the conservation of the Drottningholm paintings, and this is a circumstance that in the long run will prove to be a mistake [36].

The challenge for Nationalmuseum was twofold: first to secure funding for the conservation of paintings, and second to minimize the need for future conservation by preventing damage to the collections. The single largest damage risk, of which Nationalmuseum was becoming increasingly aware around this time, was the environment in storage and display areas.

With the development of a national electrical network supplied with energy coming from recently constructed hydro plants in northern Sweden, electrical power became available in quantities that were not seen before. Hydro plants produced electricity seven days a week, but from Saturday afternoon to Sunday morning the demand was low as the manufacturing industry closed down. As the hydro plants were government-owned their supply could therefore be directed to needs other than those of industry. Thus the idea was conceived that surplus electricity could be used to heat churches and other large historic buildings owned by the government [37]. In 1922 the first experiments for heating Gripsholm Castle (and the churches of some rural parishes) were carried out by Vattenfallsstyrelsen, the national authority for the management of hydro plants.

At this time the complete portrait collection was being reviewed for cataloguing and in order to determine its conservation needs. The curator at the castle, Sixten Strömbom, wanted a more stable environment at Gripsholm to avoid the necessity of repeating expensive conservation work. In cooperation with Strömbom, the electrical engineer Frits Jacobsson was given the task to increase the interior temperature and to decrease the RH in wintertime. Jacobsson's idea was that a moderate level of heating would keep the RH level more stable and thus counter the most extreme swings in temperature and humidity. Strömbom gave Jacobsson instructions on what kind of climate should be achieved. He understood that opening doors and windows in spring to let heat in was particularly damaging, as moisture would condense on indoor surfaces. To provide the increased heat, electric stoves were installed in the old tiled stoves that were located in most rooms, and the wiring was concealed by running it through the flues. In a similar fashion to the installation of the Perkins system in Nationalmuseum, heating devices were not meant to be visible in the museum environment as they were considered ugly.

Jacobsson paid close attention to Strömbom's explanation of the collection's environmental needs, including temperature and RH levels:

The variations in temperature make the canvas and the paint layers on the pictures change their volume, whereby the paint eventually cracks and flakes. Changes in temperature are less damaging when they occur slowly. The aim is to have an even temperature all year around. The influence of moisture transforms the structure of the varnish so that it becomes opaque. The varnish could be restored to its original state by being treated with spirits, but this work is expensive, and that is why it is preferable that the galleries where the paintings hang are kept relatively dry. However, one should avoid exposing the paintings to too hot air, since the paint layer if heated too much will lose its elasticity and crumble [35].

It is interesting that Jacobsson was also sensitive to the risks associated with opening doors and windows, which caused the most abrupt shifts in temperature. Apparently, in the early 1920s some paintings were taken down in December and stored until June, when visitors were let inside, in order not to have them damaged by condensation on the walls.

The first measures were taken in November and December 1922. The outdoor average temperature was $-2.55^{\circ} \mathrm{C}$ with a temperature of $-0.75^{\circ} \mathrm{C}$ on the first floor, and $-1.14^{\circ} \mathrm{C}$ on the third floor. These values were recorded by Frits Jacobsson. In the beginning RH levels were not recorded.

When Jacobsson experimented with electric stoves for the first time, during March-April 1923, the temperature quickly rose to as much as $18.5^{\circ} \mathrm{C}$ on the first floor (while the temperature on the third floor reached a maximum of $6^{\circ} \mathrm{C}$ ), resulting in the drying and shrinking of the wood furnishings such as wall panels, doors and ceilings. Parts of a Renaissance cassette ceiling fell to the floor and the shrinkage of the wooden interiors was clearly visible to the eye. Jacobsson's electric heaters forced a complete shutdown of all heating for two weeks because of this damage. 


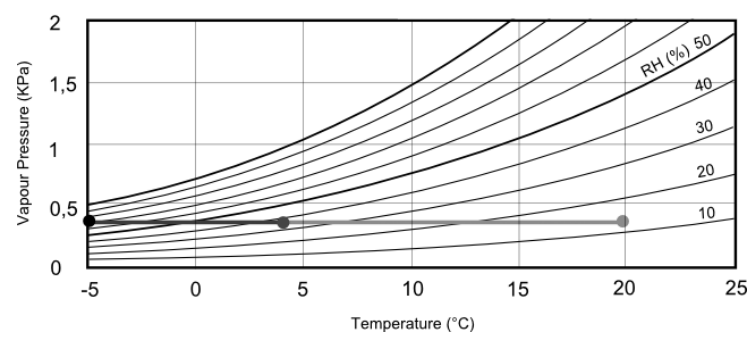

Figure 6 Mollier diagram showing the decrease in $\mathrm{RH}$ when temperature is raised first from -5 to $+4^{\circ} \mathrm{C}$ (dark gray line), and then from +4 to $+20^{\circ} \mathrm{C}$ (light gray line). Figure drawn by G. Leijonhufvud.

On the positive side, there proved to be no problem in decreasing the RH. However, the problem was to avoid excessive RH reduction by an increase in temperature, with the attendant risk of dehydration of wooden objects and furnishings. The Mollier diagram in Figure 6 shows the effect on RH with increased temperature: if outdoor air at $70 \% \mathrm{RH}$ and a temperature of $-5^{\circ} \mathrm{C}$ is brought indoors and heated to $+4^{\circ} \mathrm{C}, \mathrm{RH}$ will drop to $35 \%$. If it is heated even more, to $20^{\circ} \mathrm{C}$, $\mathrm{RH}$ will drop below 15\%. This decrease of $\mathrm{RH}$ will have a dehydrating effect on organic materials subjected to the air. Even though the relation between outdoor and indoor RH was poorly understood at the time, the curator at Gripsholm realized that both temperature and $\mathrm{RH}$ level would have to be measured in order to determine and maintain an adequate climate. After the first experiment a hydrograph was installed to record shifts in the RH level. Strömbom does not seem to have specified a desired $\mathrm{RH}$ range, apart from a statement that the $\mathrm{RH}$ level should not be allowed to exceed $80 \%$. Curiously enough, he did not give advice on a lower limit for RH.

From the trials conducted in 1922-1925 it was concluded that it was technically feasible to raise the temperature on the first floor $7.5^{\circ} \mathrm{C}$ above the outdoor temperature from the beginning of November to the end of May. The energy consumption for one season was calculated at about $265,000 \mathrm{kWh}$, which raised the question if this could be considered economically feasible. Electricity was expensive compared to other fuels such as coke, but it was considered a suitable solution since electric heaters were easily installed and when turned on they would give off heat immediately. The reasons for installing electric heaters in churches in the 1920 s were identical.

The heating scheme of Jacobsson was put into action after 1925, but required some fine-tuning over the following years. In 1931 a written instruction was issued for the management of the system [38]. In this instruction, the keeper was advised to keep a daily record of both temperature and RH levels in order to map variations over the year. The stoves would go on when the indoor temperature went down to $4^{\circ} \mathrm{C}$, or when the $\mathrm{RH}$ level rose beyond $85 \%$. This instruction was based on several years of testing of how the environmental control achieved with the electric heating could be optimized.

The attempts to eliminate extreme variations in climate at Gripsholm thus preceded, and probably also fueled, demands for a modern solution for the indoor climate in the Nationalmuseum building. The investigations of Jacobsson and Strömbom were primarily focused on attempting to keep the temperature stable. Humidity was not considered to be of critical importance for the conservation of the paintings or the building. However, over the space of a few years things were about to change. Even though curators had only a dim notion of the effects of humidity, the RH levels that were recorded at Gripsholm Castle in May 1923 were surprisingly close to those that would form the basis for future international norms over the following decades. On the first floor, $\mathrm{RH}$ levels rose from $50 \%$ in the beginning, to $63 \%$ at the end of May. On the third floor, levels were much more unstable, varying between 57 and $80 \%$ in the same period. Unfortunately, the outdoor RH was not recorded, which shows that the interplay between the building and the outdoor environment was not considered. During the trials attention was solely paid to the indoor climate, and not how it was affected by outdoor temperature.

\section{DEMANDS FOR A NEW HEATING INSTALLATION AT NATIONALMUSEUM, 1923-1927}

In 1923 an incident at Nationalmuseum made some of the problems with the existing heating system painfully apparent. The walls of the French gallery had recently been repainted, but soon it became clear that the hot water pipes caused dirt deposition, making the newly renovated gallery look old and grimy. Curator Axel Gauffin attempted to reduce the blackening effect by installing an oak bench on the walls, just above the heating conduits in the floor [39]. However, this had little, if any, effect. The blackening just hit the wall at a higher level, and after an accident in which a visitor stumbled over the bench and damaged a painting, the bench was removed. This, most probably together with other occurrences, caused Gauffin to officially condemn 
the Perkins oven as being hopelessly outdated and unsuitable for a modern museum building:

the outmoded heating device of the building, as unsound for the visitor and the staff as for the objects of art, and whose replacement with a new system will prove necessary in short, also for the reason that with the existing system heating the museum in the evenings is impossible. Because of this, an obstacle for the progression of the museum into an educational institution for the people has been laid [40].

The argument, thus, was that the existing device was a risk both for collections and humans. If Nationalmuseum was to become an institution that was attractive and available to the public, it should also offer a comfortable environment. The management's discontent with the Perkins oven was not a novelty in itself, but what were the circumstances that made it clear to the government that Nationalmuseum finally needed a new system?

The campaign for a new heating system that Gauffin initiated in 1923 continued over the following years. He argued that heat and dirt from the pipes that were located almost directly beneath the paintings caused permanent damage to the art objects. On account of this, he requested that the National Board of Building and Planning (which managed the building) make a serious investigation into the design of a new system [41]. In 1925, a committee was appointed to investigate the needs of the museum, with Gauffin as one of its members.

At this time there was also a desire to extend opening hours later into the evening, which would require artificial illumination, thus necessitating the electrification of the museum. Gauffin's intention also was that the museum should be able to guarantee the preservation of art on display, as well as that which would be stored for later display. Good storage facilities with suitable climatic conditions were thus necessary, since 'these separated objects have the same right as the displayed ones to be preserved for the future, - until the day when they perhaps are valued again - the verdict of what is valued and what is unimportant is cast anew by every generation' [42]. In these words, Gauffin summarized much of the ethos of modern conservation ideology. If nothing of the collections was to be sacrificed, adequate storage had to be organized for all the collections.

In the annual reports of 1926 and 1927, the Perkins ovens were described as a threat to both staff and collections. A fire inspection resulted in the discovery that wood in the floor had charred due to the heat from the pipes. There was obviously the risk of a fire breaking out, with disastrous consequences for the national treasures. Moreover, if a pipe was to blow and destroy a valuable piece of art, the loss would be far greater than the cost of a new heating system.

On the other hand, if the museum was to be heated and illuminated at night, it would have every chance of becoming a popular institution with an important educational mission. Before 1930, the museum was available to working people only on Sunday afternoons. In the weekdays the museum closed before most people left their work. Despite this, the museum was a popular place to visit for the people of Stockholm: in 1928, the museum had 172000 visitors, and in 1929, 110000. As the number of visitors did not increase above this level until after World War II, it is clear that the renovation of the building did not have any immediate influence on the popularity of the museum [43].

A combination of arguments together motivated the expensive removal of the old oven and the installation of a modern heating and ventilation system, together with electricity. It is possible to list the articulated needs as follows according to the main themes of 'human comfort' and 'conservation':

Human comfort needs:

- increased opening hours; and

- improved air quality.

Conservation needs:

- more stable temperature and RH level;

- cleaner air, less dirt;

- decreased risk of fire; and

- easier to clean with vacuum cleaners.

\section{THE INTRODUCTION OF FORCED AIR VENTILATION AND HUMIDITY CONTROL AT NATIONALMUSEUM, 1927-1932}

The National Board of Building and Planning gave the task of designing a heating and ventilation system to the ventilation engineer Hugo Theorell, who had long experience of working with historical buildings. Among other projects, he had installed central heating in the Royal Palace in 1912. Theorell would have to find a solution that would meet several requirements [44]: 
- a climate suitable for collections;

- a climate suitable also for humans; and

- an aesthetically acceptable design.

Theorell suggested a solution in which hot water would be distributed to radiators placed in niches in the galleries, but this was rejected by the museum. Radiators were deemed acceptable in offices and small display rooms, but not in the galleries. This decision was in keeping with aesthetic norms for art galleries of the time, as radiators were considered ugly and reduced the surfaces available for displaying art. Indeed, Nationalmuseum needed more space for displays, not less.

In 1929-1931 the extensive work of installing heating, ventilation and electricity was carried out. The hallway and the galleries would be heated by air coming from three heating chambers. Air was taken in from the museum entrance, filtered and heated, but not humidified. Gauffin had worried that panels and frames of wood would run the risk of being dehydrated, as had happened at Gripsholm before, but Theorell did not consider this to be a serious risk. In his final report, Theorell did not contemplate the importance of RH levels, only considering that temperature was not supposed to vary abruptly. Clearly the lessons from Gripsholm, which demonstrated the risks of low RH to panel paintings, had not been learnt. However, the effects of a much drier indoor environment quickly became evident to the curator. Clearly, the last two requirements - human comfort and aesthetics - were considered to be the most important, whereas the climatic needs of the collections were undervalued by the engineer. The indoor temperature was raised as visitors were no longer required to enter the galleries wearing their outer garments.

The powerful intake of outdoor air made the interior climate of the museum very dry during the first winter. Previously the natural ventilation of the building had resulted in a much lower level of air exchange with the exterior than that now achieved by the electric fans, which ran continually during opening hours. Gauffin's fears were realized. In particular, panel paintings in the Dutch collection began to show cracks. The new ventilation system needed to be supplemented with humidifiers quickly [45]. Accordingly, Nationalmuseum was the first museum in Sweden to obtain mechanically humidified air. It would appear that the installation of humidifiers in 1932 satisfied the museum for the time being. Issues of humidity do not appear in sources again at Nationalmuseum until the 1950s, when additional humidification was required to meet the new conservation norms of indoor climate. The director, Otte Sköld, wrote in 1955 that the collections, especially furniture but also paintings on panels, had to be conserved a few years after World War II. During the war the collections had been deposited in Skansenberget, an underground storage space, where $\mathrm{RH}$ and temperature had been very stable. Upon their return to the museum the objects had soon been damaged by the dry air and unstable temperature caused by the forced air ventilation system. Sköld stressed the importance of keeping a stable $\mathrm{RH}$ in order to preserve polychrome wood [46].

\section{DEVELOPMENT IN THE 1930S}

The 1930s was a period of unmatched museum building in Sweden, and it was during this time that the issue of museum climate was thoroughly discussed for the first time [47]. Nationalmuseum's heated and humidified air system was examined at the 1932 annual meeting of the Scandinavian Association of Museums [48]. The 1932 meeting made apparent the necessity to develop a more scientific knowledge base on how climate affected collections. While it was relatively easy to measure temperature and RH levels, nevertheless Sigurd Curman, the director of antiquities, wished to know what variations in climate did to different materials [49]. Therefore, changes in the indoor climate needed to be monitored along with the reactions of collections. To the author's knowledge, this type of research was not carried out in Sweden in the 1930s, or at least it was not documented, but it has been shown here that experiments had been carried out at Gripsholm Castle previously. In the 1930 s a number of national and regional museums were planned and many were also built, but the experiences from Nationalmuseum, where the introduction of a new heating and ventilation system had caused polychrome wood to crack and its paint to blister, do not seem to have been used very efficiently. It appears that limited communication between curators and engineers were obstacles standing in the way of a more profound understanding of the museum environment. In 1932, almost all attention on indoor climate was focused on keeping temperature stable, whereas RH was not considered very important. After 1932, because of the problems with dehydration following the installation of a forced air ventilation system without a humidifier, more attention was paid to the relationship between temperature and RH at Nationalmuseum. With increasing expectations on environmental control, the system from 1930 would soon prove to be less than satisfying. 


\section{REFERENCES}

1 Cooper, G., Air-Conditioning America: Engineers and the Controlled Environment, 1900-1960, Johns Hopkins University Press, Baltimore (1998).

2 Michalski, S., 'Relative humidity: a discussion of correct/ incorrect values', in ICOM 10th Triennial Meeting in Washington, DC, 22-27 August 1993, ICOM Committee for Conservation, Paris (1993) 624-629.

3 Brommelle, N., 'Material for a history of conservation: the 1850 and 1853 reports on the National Gallery', Studies in Conservation 2 (1956) 176-188.

4 Plenderleith, H.J., 'A history of conservation', Studies in Conservation 43 (1998) 135.

5 Caygill, M.L., 'The protection of national treasures at the British Museum during the First and Second World Wars', in Materials Issues in Art and Archaeology III: Symposium Proceedings No. 267, ed. P.B. Vandiver, J.R. Druzik, G.S. Wheeler, and I.C. Freestone, Materials Research Society, Pittsburgh (1992) 29-99.

6 Boothroyd Brooks, H., Practical Developments in English EaselPainting Conservation, c. 1824-1968, from Written Sources, unpublished doctoral dissertation, Courtauld Institute of Arts, London (1999) 32-35.

7 Gilberg, M., 'Friedrich Rathgen: the father of modern archaeological conservation', Journal of the American Institute for Conservation 26(2) (1987) 105-120.

8 Brown, J.P., and Rose, W.B., 'Humidity and moisture in historic buildings: the origins of building and object conservation', $A P T$ Bulletin 27 (1996) 12-23.

9 Aronson, M., 'The conservation history of the Early Italian collection at Yale', in Early Italian Paintings: Approaches to Conservation, ed. P.S. Garland, Yale University Press, New Haven and London (2003) 30-53.

10 Bewer, F.G., A Laboratory for Art: Harvard's Fogg Museum and the Emergence of Conservation in America, 1900-1950, Harvard Art Museum/Yale University Press, Cambridge, MA, New Haven and London (2010) 62.

11 McCabe, J.W., 'Humidification and ventilation in art museums', Museum News September 1 (1931) 7-8.

12 Erhardt, D., Tumosa, C.S., and Mecklenburg, M.F., 'Applying science to the question of museum climate', in Museum Microclimates, ed.T. Padfield and K. Borchersen, Nationalmuseet, Copenhagen (2007) 11-18.

13 MacIntyre, J., 'Air conditioning for Mantegna's cartoons at Hampton Court Palace', Technical Studies in the Field of the Fine Arts 2 (1934) 171-184.

14 [von Dardel, F.], 'Ett besök i Nationalmuseum', Tidskrift för byggnadskonst och ingeniörwetenskap, Stockholm (1866) 2-9.

15 Sander, F., Nationalmuseum. Bidrag till taflegalleriets historia, Vol. 4 , Samson \& Wallin, Stockholm (1876) 1.

16 Hall, T. (ed.), Nationalmuseum. Byggnaden och dess historia, Nationalmuseum, Stockholm (1976).

17 von Malmborg, B., Nationalmusei byggnad. Ett bidrag till dess tillkomsthistoria, Nationalmuseum, Stockholm (1941) 113.
18 Ierley, M., The Comforts of Home: The American House and the Evolution of Modern Convenience, Clarkson Potter, New York (1999) 127.

19 Willmert, T., 'Heating methods and their impact on Soane's Work: Lincoln's Inn Fields and Dulwich Picture Gallery', Journal of the Society of Architectural Historians 52 (1993), 26-58.

20 Riksarkivet (RA), Överintendentsämbetet (ÖÏ̈), Vol. Flab:56, dnr 288, 5 April 1866.

21 RA, ÖIÄ,Vol. FIab:55, letter from C. Bolinder to A.W. Brunius, 8 April 1863.

22 The Nationalmuseum (NM), protocols in museum matters, Vol. A2:4, protocol, 8 April 1869.

23 RA, ÖIÄ,Vol. FIab:55, report by Styffe, Bolinder and Edlund, 8 February 1864.

$24 \mathrm{NM}$, protocols in museums matters, Vol. A2:59, form for fuel consumption 1923-1924.

25 RA, ÖIÄ, Vol. FIab:55, report by Edlund and Folks, 29 December 1864.

26 RA, ÖIÄ, Vol. F1ab:60, folder on steam heat, 9 September 1915.

27 RA, ÖIÄ, Vol. FIab:58, letter from Hildebrand, 8 December 1902.

28 RA, ÖIÄ,Vol. FIab:58, staff letter, 25 February 1905.

29 RA, ÖIÄ,Vol. FIab:55, inspection report, 16 June 1863.

30 RA, ÖIÄ. Fire hazards:Vol. FIab:59, staff letter, 16 August 1915. Rotting in the basement:Vol. Flab:57, staff letter, 26 June 1889.

31 RA, ÖIÄ,Vol. FIab:55, dnr 48, 16 February 1864.

32 RA, Kungl. Byggnadsstyrelsen (KBS), Intendentsbyrån, Vol. F1A:116, letter from Janse, 18 February 1919.

33 RA, KBS, Vol. F1A:116, letter from Otto Janse, 18 February 1919, and letter from Hugo Theorell, 11 March 1919.

34 Nordensvan, G., Gripsholm. Slottets forna och nuvarande utseende, konstskatter och omgifningar, Norstedts, Stockholm (1880).

35 Jacobsson, F., Effektbehovet vid elektrisk uppvärmning av kyrkor samt uppvärmningsförsök $i$ Gripsholms slott, Kungl. Vattenfallsstyrelsen, Stockholm (1926).

36 Meddelanden frän Nationalmuseum nr 49, Nationalmuseum, Stockholm (1924) 22.

37 'Öfverintendentsämbetets utlåtande om kyrkors uppvärmning medelst elektricitet', Teknisk tidskrift 6 (1916) 67-72, 76-80.

$38 \mathrm{NM}$, protocols in museum matters, Vol. A2:66, instruction dated 2 March 1931.

39 NM, protocols in museum matters, Vol. A2:58, 3 May 1923.

40 Meddelanden frän Nationalmuseum $n r$ 48, Nationalmuseum, Stockholm (1923) 4.

$41 \mathrm{NM}$, protocols in museum matters, Vol. A2:59, 11 November 1924.

42 Meddelanden frän Nationalmuseum nr 49, Nationalmuseum, Stockholm (1923) 20.

43 Bjurström, P., Nationalmuseum 1792-1992, Nationalmuseum, Stockholm (1992).

44 SOU 1931:8, Ny värmeledning samt elektrisk belysningsanläggning i Nationalmuseibyggnaden $i$ Stockholm, Kungl. Byggnadsstyrelsens meddelanden 3, Stockholm (1931).

45 RA, KBS, Intendentsbyrån,Vol. F1 A:124, Bildmark's staff letter, 1 September 1931. 
46 Antikvarisk-topografiska arkivet, Kulturhistoriska byrån, Vol. F3ca:9, Otte Sköld's letter, 8 September 1955.

47 Legnér, M., 'För människans väl, eller föremålens? Komfort, bevarande och innemiljö i 1920- och 30-talens museer', in Gotlandsakademiker tycker om, ed. A. De Ridder and $\AA$. Sandström, Gotland University Press 8,Visby (2010) 45-58.

48 Skandinaviska museiförbundet - Berättelse över mötet $i$ Lund och Malmö 31 maj - 4 juni 1932, Nordisk Rotogravyr, Stockholm (1932).

49 Curman, S., 'Museibyggnader', Byggmästaren. Arkitektupplagan 3(8) (1933) 33-43.

\section{AUTHOR}

Mattias Legnér was born in 1973, and holds a PhD in History. He is Associate Professor in Conservation at Gotland University,Visby, Sweden, and currently heads the research project 'Cultural heritage and human comfort: The issue of indoor climate in historic buildings in the twentieth century', funded by the Swedish Research Council (project \# 2009-2375). He is also involved in a research and development project at Gotland University called 'Sustainable management of cultural heritage', running 2011-2013. Address: Gotland University, S-62167 Visby, Sweden.Email: mattias.legner@hgo.se

Résumé - Malgré le fait qu'il y ait eu des enquêtes sur l'évolution historique des recommandations relatives au climat intérieur, à ce jour très peu de recherches ont été menées sur la façon dont le contrôle du climat dans les musées a été effectivement mis en ceuvre dans le passé. Cet article examine le développement du contrôle climatique dans deux bâtiments de musées suédois jusqu'aux années 1930: le Nationalmuseum et le château de Gripsholm. Le Nationalmuseum a été construit pour rendre les collections nationales plus accessibles au public et pour assurer une surveillance et un chauffage central. A cette époque la connaissance des conditions climatiques dans les musées était tacite et basée sur l'expérience personnelle plutôt que sur des études scientifiques. Toutefois, dès le début du XXe siècle, le problème de la gestion du climat muséal augmenta car les conservateurs devinrent plus conscients de l'effet déshydratant du chauffage central sur les panneaux en bois et sur les bois polychromes. Les premières tentatives réussies pour contrôler automatiquement le climat intérieur ont été réalisées à Gripsholm dans les années 1920. L'accent était alors mis sur le suivi et le contrôle de la température plutôt que sur celui de l'humidité relative, mais ces premières tentatives ont également démontré que les niveaux extrêmes d'humidité pouvaient être évités dans un environnement qui n'avait jamais été conçu pour un chauffage permanent. Cet article examine les tentatives de gestion du climat intérieur entre les années 1860 et 1930 .

Zusammenfassung - Obwohl sich einige Forschungsarbeiten mit der historischen Entwicklung der Empfehlungen zur KlimaKontrolle von Innenräumen beschäftigt haben, gibt es bisher keine Untersuchungen, wie in der Vergangenheit Klimakontrollen in Museen tatsächlich ausgeführt wurde. In dieser Arbeit wird die Entwicklung der Klimakontrolle bis in die 1930er Jahre in zwei schwedischen Museumsgebäuden, dem Nationalmuseum und Schloss Gripsholm untersucht. Das Nationalmuseum wurde gebaut, um die Staatlichen Sammlungen dem Publikum besser zugänglich zu machen und gleichzeitig eine bessere Überwachung und Zentral-Heizung einzuführen. Zu dieser Zeit gab es zwar ein gewisses Wissen über Klimatische Bedingungen in Museen; dieses basierte aber eher auf persönlichen Erfahrungen als auf wissenschaftichen Untersuchungen. Anfang des 20. Jahrhunderts begann allerdings die Problematik der Museumsklimata bekannter zu werden, da den Kuratoren die Gefahr der Austrocknungs-Effekts der Zentral-Heizung auf Tafelgemälde und polychrom gefasstes Holz immer bewußter wurde. Die ersten erfolgreichen Versuche automatisch kontrollierter Regulierung von Innenraumklimata wurden in Schloss Gripsholm in den 1920er Jahren durchgeführt. Das Hauptangenmerk war damals auf die Aufzeichnung und Kontrolle der Temperatur gerichtet und galt nicht der relativen Luftfeuchtigkeit., doch zeigten diese frühen Versuche, dass extreme Luftfeuchte-Werte auch in einer Umgebung vermieden werden konnten, die nie für ein permanentes Heizen gedacht war. Dieser Artikel untersucht Versuche zur Kontrolle des Innenraumklimas zwischen den 1860 er und 1930 er Jahren.

Resumen - A pesar de que existen ciertas investigaciones sobre el desarrollo histórico de las recomendaciones en cuanto al control climático en interiores, hasta la fecha se han llevado a cabo escasas investigaciones sobre las mejoras realizadas a través del tiempo en lo que a control climático en museos se refiere. Este artículo examina el desarrollo del control ambiental en dos edificios de museos suecos hasta los años treinta: el Nationalmuseum y el Castillo Gripsholm. El Nationalmuseum se construyó con el fin de hacer las colecciones nacionales más accesibles al público, aportando control ambiental y calefacción. En ese momento 
el conocimiento de las condiciones climáticas en museos era intuitivo y se basaba más en las experiencias personales que en estudios científicos. Sin embargo a comienzos del siglo XX el problema del control ambiental se incrementó al ser conscientes los conservadores de los efectos de la deshidratación por efecto de las calefacciones, especialmente en las pinturas sobre tabla y en la escultura policroma. Los primeros intentos que tuvieron éxito para controlar automáticamente el clima en interiores se realizaron en Gripsholm en los años veinte. Estos ensayos se centraron más en la monitorización y control de la temperatura que en la humedad relativa, pero estas pruebas tempranas mostraron también que podían ser evitados niveles extremos de humedad en ambientes que no habían sido diseñados originalmente para tener sistemas de calefacción permanentes. Este artículo estudia las pruebas de control ambiental realizadas entre 1860 y 1930 aproximadamente. 